\title{
TRADISI MASYARAKAT NELAYAN RAWA PENING KELURAHAN BEJALEN KECAMATAN AMBARAWA KABUPATEN SEMARANG
}

\author{
Olvi Cristianawati \\ Program Magister Sumberdaya Pantai \\ Universitas Diponegoro Semarang
}

\begin{abstract}
Bejalen village is located in Ambarawa subdistrict which has 470,720 hectars. There are 14,040 hectars of ponds and about 86 hectars rice fields as a good source for fish and agritultural production. The agricultural output reached 14,040 tons of crops and the production of fish amounted 1,533 tons. The Livelihood of community is fishermen. They work everyday based on the old generation tradition. The research purpose has gained more information about the fishermen culture, such as social, economic, and organisational condition.
\end{abstract}

Keywords: culture, fishermen, swamp, social, economic, and organisational condition

\section{Pendahuluan}

\subsection{Latar Belakang}

Desa Bejalen terletak di Kecamatan Ambarawa, Kabupaten Semarang yang mempunyai wilayah desa seluas 470,720 ha dengan batas-batas desa, di sebelah utara terdapat kelurahan lodoyong, kelurahan kupang dan kelurahan Tambak Boyo. Di bagian selatan terdapat desa Banyu Biru, di sebelah timur juga terdapat desa Tuntang dan di sebelah barat terdapat kelurahan Pojok Sari. Di sana terdapat tambak dan sawah dengan luas areal tambak sebesar 14.040 ha dan sawah sebesar 86 hektar yang digunakan sebagai sumber produksi ikan yang baik. Hasil pertanian mencapai 14.040 ton palawija dan produksi ikan/tambak berjumlah 1.533 ton.

Kajian penelitian ini tertuju pada sebagian besar kehidupan sosial ekonomi dan masyarakat nelayan khususnya yang tergolong nelayan buruh atau nelayannelayan kecil yang hidup dalam kemiskinan. Kemiskinan nelayan merupakan salah satu masalah sosial yang sangat serius, yang selalu tumbuh pada setiap dimensi dari sendi-sendi (Setyorini, 2013). Kemampuan mereka untuk memenuhi kebutuhan dasar minimal kehidupan sehari-hari sangat terbatas. Bagi masyarakat nelayan, di antara beberapa jenis kebutuhan pokok, kehidupan yang paling penting adalah pangan. Menurut Kusnadi (2006), adanya jaminan pemenuhan kebutuhan pangan setiap hari berperan besar untuk menjaga kelangsungan hidup mereka.

$$
\text { Menurut Satria (2002), }
$$

keterbelakangan dan kemiskinan bukanlah cerita baru bagi masyarakat pesisir. Berdasarkan ukurannya, kemiskinan dibagi menjadi dua kemiskinan absolute dan kemiskinan relative. Kemiskinan absolute adalah masyarakat yang secara alamiah benar-benar miskin berdasarkan ketentuan ukurannya. Sementara itu, kemiskinan relative merupakan kemiskinan dan suatu kelompok pendapatan bila dibandingkan dengan kelompok pendapatan lainnya.

Aspek struktural menyebabkan lemahnya posisi nelayan atau pembudidaya ikan dalam pemasaran. Proses tawar menawar menyebabkan para nelayan sangat lemah dan tidak berdaya karena hasil produksi mereka yang masih minim. Selain itu, desakan kebutuhan yang memaksa nelayan untuk menerima tawaran harga dan pasar meskipun harga tersebut sangat merugikan nelayan. Dengan demikian kajian tentang pemberdayaan untuk mengatasi masalah para nelayan, kemiskinan dan keterbelakangan sangat penting. 


\subsection{Tujuan}

Penelitian ini bertujuan untuk mengetahui tradisi masyarakat nelayan yang meliputi dimensi sosial, ekonomi, budaya, dan kelembagaan.

\subsection{Waktu dan Tempat}

Kegiatan penelitian Sosiologi Masyarakat Perikanan dilaksanakan di Desa Bejalen, Ambarawa, Propinsi Jawa Tengah.

\section{Tinjauan Pustaka}

\subsection{Pengertian Masyarakat Perikanan}

Definisi masyarakat menurut Hortono et. al (1991) adalah sekumpulan manusia yang secara relatif mandiri, cukup lama hidup bersama, mendiami suatu wilayah tertentu, memiliki kebudayaan yang sama, dan melakukan sebagian besar kegiatannya di dalam kelompok tersebut. Menurut Sitorus et. al (1998), masyarakat sebagai kelompok manusia telah lama hidup dan bekerja sama cukup lama. Sementara itu Soekanto (1990) merinci unsur-unsur masyarakat sebagai berikut:

1. manusia yang hidup bersama;

2. bercampur dalam waktu yang lama;

3. sadar sebagai suatu kesatuan; dan

4. sadar sebagai suatu sistem hidup bersama.

Wilayah pesisir adalah daerah pertemuan antara darat dan laut, dengan batas ke arah darat meliputi bagian daratan, baik kering maupun terendam air yang masih mendapat pengaruh sifat-sifat laut seperti angin laut, pasang surut, perembesan air laut (intrusi) yang dicirikan oleh vegetasinya yang khas, sedangkan batas wilayah pesisir ke arah laut mencakup bagian atau batas terluar dari daerah paparan benua (continental shelf), di mana ciri-ciri perairan ini masih dipengaruhi oleh proses alami yang terjadi di darat seperti sedimentasi dan aliran air tawar, maupun proses yang disebabkan oleh kegiatan manusia di darat seperti penggundulan hutan dan pencemaran (Pagorray, 2003).

\subsection{Dimensi Sosial Masyarakat Perikanan}

Soekanto (1995) menyatakan bahwa stratifikasi sosial adalah pembedaan penduduk atau masyarakat ke dalam kelaskelas secara bertingkat atau sistem berlapis-lapis dalam masyarakat. Stratifikasi sosial merupakan konsep sosiologi, dalam artian kita tidak akan menemukan masyarakat seperti kue lapis, tapi pelapisan adalah suatu konsep untuk menyatakan bahwa masyarakat dapat dibedakan secara vertikal menjadi kelas atas, menengah, dan bawah berdasarkan kriteria tertentu. Jadi, stratifikasi sosial adalah dimensi vertikal dan struktur sosial masyarakat, dalam artian melihat perbedaan masyarakat berdasarkan pelapisan yang ada, apakah berlapis-lapis secara vertikal dan apakah pelapisan tersebut terbuka atau tertutup.

\subsection{Dimensi Ekonomi Masyarakat Perikanan}

\subsubsection{Pendapatan dan Pengeluaran}

Menurut Badan Pusat Statistik (2005), pengeluaran rumah tangga merupakan salah satu indikator yang dapat memberikan gambaran keadaan kesejahteraan penduduk. Semakin tinggi pendapatan, maka porsi pengeluaran akan bergeser dan pengeluaran untuk makanan ke pengeluaran bukan makanan. Pergeseran pola pengeluaran terjadi karena elastisitas permintaan terhadap barang bukan makanan pada umumnya tinggi.

Pendapatan dan pengeluaran yang diperoleh masyarakat pesisir dalam satu bulan berbeda-beda, ada masyarakat yang mampu mencukupi kebutuhan hidupnya dalam satu bulan, namun ada juga masyarakat pesisir yang tidak dapat mencukupi kebutuhan hidupnya, dikarenakan keterbatasan biaya, dan banyaknya kebutuhan yang harus dipenuhi (Nurmalasari, 2005).

\subsubsection{Pola Kegiatan}

Pola kegiatan adalah pola kerja yang dilakukan masyarakat perikanan 
sehari-hari, mencakup seberapa lama mereka melakukan kegiatan kerja, baik penangkapan, pengolahan ikan, maupun pembudidayaan dan kegiatan non kerja seperti istirahat, tidur, dan kegiatan lainnya. Pola kegiatan akan dapat menggambarkan jam kerja masyarkat perikanan (Kistanto, 1997).

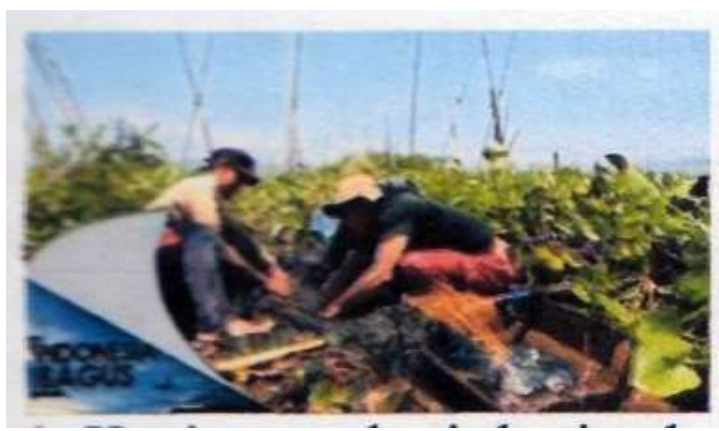

Gambar 1. Kegiatan sehari-hari nelayan desa Bejalen

\subsubsection{Peran Wanita}

Istri nelayan umunmya hanya menjalankan fungsi domestik dan ekonomi dan tidak sampai pada wilayah sosial politik. Namun, sebenarnya istri nelayan kreatif juga dalam menghasilkan pranata sosial yang penting bagi stabilitas sosial komunitas nelayan. Peran wanita merupakan faktor penting dalam menstabilkan ekonomi di beberapa masyarakat perikanan. Istri nelayan biasanya dominan dalam mengatur pengeluaran rumah tangga sehari-hari sehingga sudah sepatutnya peranan istri masyarakat perikanan menjadi salah satu pertimbangan dalam setiap program pemberdayaan (Nurmalasari, 2005).

\subsection{Dimensi Budaya Masyarakat Perikanan}

\subsubsection{Kearifan Lokal}

Kearifan lokal merupakan bagian dari sistem budaya, biasanya berupa larangan-larangan yang mengatur hubungan sosial maupun hubungan manusia dengan lingkungan alamnya. Setiap masyarakat perikanan memiliki unsur kebudayaan seperti sistem kemasyarakatan, sistem mata pencaharian, sistem kepercayaan, bahasa dan kesenian serta melaksanakan pola-pola hidup sendiri. Hal inilah yang menunjukkan karakterisitik budaya masyarakat perikanan itu sendiri. Setiap masyarakat akan mengembangkan kearifan lokal sesuai dengan kondisi lingkungan sosialnya maupun lingkungan alamnya serta sistem pengetahuan yang dimilikinya. Contoh kearifan lokal yang terdapat di etnis Bengkulu, seperti: pada etnik Enggano yang berdomisili di wilayah berekosistem pulau/pesisir mempunyai kearifan lokal dalam pengelolaan sumberdaya hutan dan kelautan (Dahuri, 1999).

Kearifan lokal berfungsi untuk menjaga kelestarian dan kesinambungan aset yang dimiliki suatu masyarakat sehingga masyarakat dapat terpenuhi kebutuhannya dan generasi hingga generasi berikutnya, tanpa menghabiskan aset tersebut. Karena itu, kearifan lokal selalu dijadikan pedoman atau acuan oleh masyarakat dalam bertindak atau berperilaku dalam praktis kehidupannya, merupakan wujud dari kesadaran terhadap hukum kausalitas (sebab-akibat) dan pemahaman terhadap hubungan yang bersifat simbiosis mutualis (Dahuri, 1999).

\section{Materi dan Metode}

Materi yang digunakan dalam penelitian ini adalah masyarakat perikanan baik penangkap (nelayan), pembudidaya, maupun pengolah ikan dilihat dari dimensi sosial, ekonomi, budaya, dan kelembagaan.

\subsection{Alat}

Alat yang digunakan untuk penelitian ini adalah alat tulis yang berfungsi untuk mencatat hasil wawancara, kertas folio untuk tempat mencatat hasil wawancana, kamera untuk mendokumentasikan kegiatan penelitian, motor untuk transportasi menuju tempat penelitian, dan jas almamater untuk tanda pengenal atau identitas diri. 


\subsection{Bahan}

Bahan yang digunakan pada penelitian ini adalah kuesioner yang digunakan sebagai bahan untuk mengajukan pertanyaan, responden sebagai narasumber untuk mengisi kuesioner, buku referensi berfungsi untuk bahan referensi dalam pembuatan laporan dan laporan monografi kelurahan berfungsi sebagai data keadaan wilayah desa Bejalen, kabupaten Ambarawa.

\subsection{Metode}

Metode yang digunakan dalam penelitian ini meliputi penentuan lokasi, yaitu survei lokasi yang telah ditentukan (tambak jauh dari lokasi industri); dan pelaksanaan penelitian dengan mengambil data sekunder melalui wawancara. Menurut Nazir (1999), metode survei adalah kegiatan mencari tahu yang diadakan untuk mencari keteranganketerangan dari suatu kelompok atau daerah secara faktual, baik tentang institusi sosial, ekonomi ataupun politik. Wawancara ini dilakukan dengan cara mendatangi dari rumah ke rumah penduduk untuk mendapatkan data. Data yang didapat kemudian dianalisis secara deskriptif. Metode deskriptif yaitu menggambarkan atau melukiskan keadaan subyek/obyek penelitian (seseorang, masyarakat dan lain-lain) berdasarkan fakta-fakta yang tampak sebagaimana adanya.

\subsection{Pengumpulan Data}

Pengumpulan data primer (baik kualitatif maupun kuantitatif) dilakukan dengan wawancara. Wawancara dilakukan dengan menggunakan daftar pertanyaan yang telah terpola dan sesuai dengan tujuan penelitian yaitu mengetahui karakteristik profil masyarakat perikanan yang meliputi dimensi sosial, ekonomi, budaya, dan kelembagaan. Pendekatan ini dipilih karena menurut Rush (1995), penelitian dengan metode survei dan pengumpulan data dengan menggunakan kuesioner akan lebih terarah dan lebih mudah mendapatkan data. Data primer yang dikumpulkan adalah data mengenai karakteristik masyarakat perikanan yang dilihat dari dimensi sosial, ekonomi, budaya, dan kelembagaan. Data sekunder diambil dengan cara mencatat data dari desa atau kelurahan mengenai potensi desa atau kelurahan tersebut.

\section{Hasil dan Pembahasan \\ 4.1. Potensi Desa}

Pemberdayaan masyarakat di desa Bejalen difokuskan pada potensi perikanan setempat guna membangun perekonomian dan meningkatkan pembangunan. Beberapa bidang yang ditekuni yaitu tertuju pada mata pencaharian sebagai nelayan perikanan tangkap, perikanan budidaya dan pengolahan perikanan.

Program pemberdayaan masyarakat dapat dilakukan melalui pendidikan dan kesehatan dan menciptakan iklim investasi yang kondusif bagi dunia usaha. Pengembangan potensi ekonomi lokal dengan menjamin keberpihakan kepada rakyat kecil, meningkatkan ketersediaan dan kualitas infrastruktur, mengembangkan perikehidupan yang agamis, berbudaya, berkesetaraan jender ramah lingkungan serta mengembangkan wisata yang berbasis perikanan dan budaya setempat seperti memanfaatkan rawa pening sebagai tempat wisata bagi masyarakat setempat dan masyarakat luar.

\subsection{Hubungan Patronage}

Menurut Mulyadi (2005), hubungan patronage adalah hubungan yang didasarkan pada asas untuk saling memberi dan saling menerima. Pola hubungan ini lebih disebabkan oleh pendapatan masyarakat perikanan yang tidak teratur, lebih banyak diliputi dengan ketidakpastian (uncertainty), sehingga adaptasi yang dikembangkan dalam komunitasnya lebih pada semacam asuransi sosial yang diperoleh melalui hubungan patronage.

Scoot (1993), melihat hubungan patron-klien sebagai fenomena yang 
terbentuk atas dasar ketidaksamaan dan sifat fleksibilitas yang tersebar sebagai sebuah sistem pertukaran pribadi. Dalam pertukaran itu, berarti ada arus dari patron klien dan sebaliknya.

Hubungan antara nelayan dengan patron yang menguasai sumberdaya tidak sama. Artinya, parton menguasai sumberdaya modal jauh lebih besar daripada nelayan. Dengan ketidaksamaan penguasaan sumberdaya itu, terjadilah ikatan patron-klien. Masyhuri (1999) menyatakan bahwa pada saat hasil tangkapan kurang baik, nelayan kekurangan uang. Pada akhirnya, ia melepas barang-barang yang mudah dijual dengan lebih murah kepada patron.

Masyarakat perikanan setempat baik itu yang bermata pencaharian sebagai nelayan mendapatkan dana untuk melaut berasal dari dana sendiri, pengolah hasil perikanan mendapatkan dana atau modal untuk mengolah hasil perikanan dan dana sendiri, sedangkan pembudidaya mendapatkan dana untuk pembudidayaan ada yang berasal dari bantuan anggota keluarga, ada pula yang berasal dari tengkulak. Kalau dana berasal dari tengkulak tersebut, maka hasil budidanya akan dibagi dua antara pembudidaya dengan tengkulak.

\subsection{Kearifan lokal yang Ada di Msyarakat}

Terdapat beberapa tradisi yang berhubungan dengan pengelolaan SDI di desa Bejalen, sehingga tidak ada peraturan adat dan pengaturannya secara tertulis. Masyarakat di sana hanya mengandalkan sanksi secara lisan atau teguran apabila ada warganya yang bertolak belakang atau melanggar peraturan. Adapun adat istiadat mengenai kelahiran antara lain adalah brokohan, puputan dan selapanan. Apabila ada kematian, maka warga sekitar mengadakan rukun kematian, yakni membatu perlengkapan yang dibutuhkan seperti pengadaan kursi, meja, dan lainlain. Untuk adat istiadat dalam hal keagamaan biasanya diadakan pengajian, peringatan Isra' Miraj, dan Maulid Nabi. Apabila terdapat masyarakat yang mempunyai hajat perkawinan, biasanya warga akan membantu dalam hal tenaga. Masyarakat Desa Bejalen tidak memiliki tradisi yang disebut sedekah laut atau yang berhubungan dengan konservasi. Menurut Koentjaraningrat (1990), kearifan lokal yang ada di masyarakat merupakan suatu bentuk budaya dan masyarakat yang telah terjadi secara turun temurun menjadi suatu kebiasaan yang tidak dapat dilanggar.

Kearifan lokal berperan penting dalam kehidupan sehari-hari masyarakat Desa Bejalen, Kecamatan Ambarawa, Kabupaten Semarang. Hubungan antar warga dapat berjalan dengan baik, harmonis, dan berkesinambungan. Hal ini dikarenakan terdapat rasa saling menghormati antar warga sekitar. Kesadaran untuk mematuhi norma dan adat istiadat yang berlaku sudah tertanam dan dijalankan dengan baik. Kearifan lokal berfungsi untuk menjaga kelestarian dan kesinambungan aset yang dimiliki suatu masyarakat, sehingga masyarakat dapat terpenuhi kebutuhannya dan generasi hingga generasi berikutnya, tanpa menghabiskan aset tersebut.

\section{Penutup}

Adapun hasil yang ingin diperoleh dari hasil penelitian Sosiologi Masyarakat Perikanan yang dilaksanakan di Desa Rawa Pening, Ambarawa, berdasarkan karakteristik profil masyarakat, yaitu:

1. Menciptakan kebijakan dan aplikasi pembangunan kawasan pesisir dan masyarakat nelayan yang terintegrasi atau terpadu di antara para pelaku pembangunan.

2. Menciptakan konsistensi kuantitas produksi (hasil tangkap) sehingga aktivitas sosial ekonomi perikanan di desa-desa nelayan berlangsung terus.

3. Mengatasi masalah isolasi geografis desa nelayan, sehingga menyulitkan keluar masuk barang, jasa, kapital, dan manusia. Berimplikasi melambatkan 
dinamika sosial, ekonomi, dan budaya masyarakat nelayan.

4. Meminimalisir modal usaha atau investasi sehingga tidak menyulitkan nelayan meningkatkan kegiatan ekonomi perikanannya.

5. Menciptakan relasi sosial ekonomi eksploitatif dengan pemilik perahu dan pedagang perantara (tengkulak) dalam kehidupan masyarakat nelayan.

6. Meningkatkan tingkat pendapatan rumah tangga nelayan yang rendah, berdampak sulitnya peningkatan skala usaha dan perbaikan kualitas hidup.

7. Menciptakan kesejahteraan sosial bagi nelayan yang berpenghasilan rendah untuk mobilitas sosial mereka.

\section{Daftar Pustaka}

Badan Pusat Statistik. 2005. "Persentase Pengeluaran Rumah Tangga: Distribusi dan Pengeluaran Rumah Tangga Kota Surabaya." Badan perencanaan pembangunan Kota Surabaya.

Dahuri, Rochmin. 1999. "Perencanaan Pengelolaan Sumberdaya Pesisir Terpadu Berbasis Masyarakat." Prosiding Rapat Kordinasi Proyek dan Kegiatan Pengelolaan Sumberdaya Pesisir dan Lautan di Indonesia. Direktorat Jenderal Pembangunan Daerah. Coastal Resources Management Project.

Horton, Paul B dan Chester L Hunt. 1991. Sosiologi. Jakarta.

http://famirania.wordpress.com/200/faktasosial/trackback/

Kistanto. 1997. "Kondisi Sosial Budaya Masyarakat Jawa. Makalah Pelatihan Peran Serta Masyarakat Dalam Pengelolaan Wilayah Pesisir." Pusat Penelitian Lingkungan Hidup, Lembaga Penelitian. UNDIP. Semarang.

Koentjaraningrat. 1990. Kebudayaan dan Mentalitas. Gramedia: Jakarta

Kusnadi. 2006. Perempuan Pesisir. Yogyakarta> LKIS.
Masyhuri (ed). 1999. "Pemberdayaan Nelayan Tertinggal dalam Mengatasi Krisis Ekonomi: Telaah terhadap sebuah Pendekatan." Jakarta: Puslitbang Ekonomi dan Pembangunan LIPI.

Mulyadi S. 2005. Ekonomi Kelautan. Jakarta: Rajawali Press.

Nazir, Moh. 1999. Metode Penelitian. Jakarta: Ghalia Indonesia.

Nurmalasari, Yessy. 2005. "Analisis Pengelolaan Wilayah Pesisir Berbasis Masyarakat." htty.//www.stmikim. ac. id/userfiles/jurnal\%20yessy.pdf. (30 Mei 2009).

Pagorray, Henny. 2003. "Lingkungan Pesisir dan Masalahnya sebagai Daerah Aliran Buangan Limbah." http://www.yahoo.com/hennypagor ay yahoo.com (23 November 2003).

Rusli.S. 1995. Metodologi Identifikasi Golongan Miskin. Grasindo, Jakarta.

Satria, Arif. 2002. Pengantar Sosiologi Masyarakat Pesisir. Jakarta: Cidesindo.

Setyorini, Heny Budi. 2013. "Budaya Kemiskinan Nelayan di Mangunharjo Semarang.: Sabda, Volume 8, Tahun 2013: 7-17.

Sitorus, Felix, Endriatmo Setiawan Soetarto dan Ivanovich Agusta. 1998. Sosiologi Umum. Bogor.

Soekanto, Soejono. 1990. Sosiologi: Suatu Pengantar. Jakarta: Radjawali Pers. 1995. Sosiologi: Suatu Pengantar. Jakarta: Radjawali Pers. 